\title{
Dampak ekspor ke Jepang dan investasi asing terhadap pendapatan perkapita masyarakat di Indonesia
}

\author{
Candra Mustika*; Erni Achmad; Etik Umiyati \\ Prodi Ekonomi Pembangunan Fakultas Ekonomi dan Bisnis Universitas Jambi \\ *E-mail korespondensi: candra.mustika@yahoo.com
}

\begin{abstract}
This study aims to analyze the development of exports to Japan and foreign direct investment and per capita income in Indonesia during the period 1993-2014 also the impact of exports to Japan and foreign direct investment on per capita income of Indonesian people in that period. During research period starting in 1993-2014 where the GDP per capita has fluctuated where the average value is 15.058 in thousand rupiahs per year with an average growth of $16.61 \%$, then the results obtained during that period the highest growth in 1998 is $50.50 \%$ and the lowest growth occurred in 2012 which was 8.46\%. FDI Indonesia has fluctuated with an average value of 17,804.61 million US dollars and with an average growth of $15.35 \%$. From the regression results on both models, the results found that in the first model the value of exports to Japan has a positive and significant effect on GDP per capita while the FDI variable does not have a positive and significant effect on GDP per capita.
\end{abstract}

Keywords: Per capita income, export, Foreign Direct Investment (FDI)

\begin{abstract}
Abstrak
Penelitian ini bertujuan untuk menganalisis perkembangan ekspor ke jepang dan investasi asing langsung serta pendapatan perkapita Indonesia selama periode tahun 1993-2014 dan menganalisis dampak ekspor ke jepang serta investasi asing terhadap pendapatan perkapita masyarakat Indonesia pada periode tersebut. Selama periode penelitian mulai tahun 1993-2014 dimana PDB perkapita mengalami fluktuasi atau naik turun dimana rata-rata nilainya adalah 15.058 dalam ribu rupiah pertahun dengan ratarata pertumbuhan $16,61 \%$, kemudian selama periode tersebut diperoleh hasil ternyata pertumbuhan tertinggi terjadi pada tahun 1998 yakni 50,50\% dan dengan pertrumbuhan terendah terjadi pada tahun 2012 yakni sebesar 8,46\%. FDI Indonesia mengalami fluktuasi atau naik turun dengan nilai rata-rata 17.804,61 Juta US Dollar dan dengan rata-rata pertumbuhan $15,35 \%$. Dari hasil regresi pada kedua model diperoleh hasil bahwa pada model pertama nilai ekspor ke jepang berpengaruh positif dan signifikan terhadap PDB perkapita sementara variabel FDI tidak berpengaruh positif dan signifikan terhadap PDB perkapita.
\end{abstract}

Kata kunci: Pendapatan perkapita, ekspor, Foreign Direct Investment (FDI)

\section{PENDAHULUAN}

Ekspor dan investasi merupakan variabel ekonomi makro yang sangat menentukan pandapatan nasional dan pertumbuhan ekonomi suatu Negara karena pertumbuhan ekonomi bisa diukur dari sisi pengeluaran diantaranya pengeluaran yang 
dilakukan oleh masyarakat,swasta dan pemerintah, serta salah satu sektor dalam perekonomian terbuka adalah perdagangan luar negeri yakni ekspor dan impor dari data yang diperoleh dalam Asian Development Bank (ADB) diantara negara-negara tujuan ekspor indonesia di dunia adalah negara Jepang dengan data tahun 1993 menunjukkan nilai ekspor sebesar 11.172 Juta US Dolar,yang menduduki peringkat pertama sebagai negara tujuan ekspor indonesia,hingga tahun 2013 nilai ekspor indonesia ke jepang meningkat menjadi 25.782 Juta US dolar, dan di antara barang-barang yang di ekspor ke jepang banyak sekali yang berasal dari sektor ekonomi kreatif, bahkan sebagai contoh sektor ekonomi kreatif di antaranya di propoinsi Bali ekspor hasil kerajinan patung mencapai 47,06\% dari total niali ekspor di bali pada tahun 2013 . Sementara selain ekspor ke Negara jepang variabel makro yang lain yakni investasi Dalam perkembangannya di Indonesia dewasa ini sudah mengalami kemajuan yang signifikan. Hal ini dapat kita lihat dari perkembangan aliran FDI di Indonesia yang mana pada tahu 1993 sebesar \$8.144,2 juta meningkat sebesar \$39.914,7 juta di tahun 1995, masuk pada tahun 2000 peningkatan FDI terjadi sebesar \$15.420,0 juta dan pada tahun 2001 turun menjadi $\$ 9.027,5$ juta. Namun pada tahun berikutnya FDI mengalami peningkatan, di tahun 2003 FDI sebesar $\$ 13.207,2$ juta atau meningkat sebesar 10,56\% dari tahun sebelumnya. Hingga pada tahun 2008 aliran FDI sebesar \$14.871,4 juta atau meningkat sekitar 4,5\% pertahun, sampai pada tahun 2013 sebesar $\$ 16.214,8$ juta. Perkembangan ekspor ke jepang dan FDI yang berfluktuasi dari tahun ketahun yang cenderung meningkat diharapkan turut berpartisipasi dalam meningkatkan pertumbuhan ekonomi dan dapat meningkatkan pendapitan perkapita,karena indikator kesejahteraan tidak hanya pertumbuhan ekonomi saja tetapi dapat dilihat dari pendapatan perkapita. Berdasarkan latar belakang tersebutlah yang memunculkan ide penelitian untuk mengetahui dan menganalisis pengaruh indikator ekonomi makro FDI dan ekspor ke jepang terhadap pendapatan perkapita Indonesia selama periode 1990 sampai 2014. Setelah melihat uraian pada bagian latar belakang kita dapat mengidentifikasi masalah yang akan diteliti pada penelitian tentang bagaimana perkembangan Ekspor ke Jepang dan FDI serta Pendapatan perkapita Indonesia selama periode 1993-2014, bagaimana pengaruh Ekspor ke Jepang dan FDI terhadap pendapatan perkapita di Indonesia selama periode 1993-2014.

\section{TINJAUAN PUSTAKA}

\section{Model Ricardian}

Model Ricardian memfokuskan pada kelebihan komparatif dan mungkin merupakan konsep paling penting dalam teori pedagangan internasional. Dalam Sebuah model Ricardian, negara mengkhususkan dalam memproduksi apa yang mereka paling baik produksi. Tidak seperti model lainnya, rangka kerja model ini memprediksi dimana negara-negara akan menjadi spesialis secara penuh dibandingkan memproduksi bermacam barang komoditas. Juga, model Ricardian tidak secara langsung memasukan faktor pendukung, seperti jumlah relatif dari buruh dan modal dalam negara.

\section{Model Heckscher-Ohlin}

Model Heckscgher-Ohlin dibuat sebagai alternatif dari model Ricardian dan dasar kelebihan komparatif. Mengesampingkan kompleksitasnya yang jauh lebih rumit model ini tidak membuktikan prediksi yang lebih akurat. Bagaimanapun, dari sebuah titik pandangan teoritis model tersebut tidak memberikan solusi yang elegan dengan memakai mekanisme harga Teori ini berpendapat bahwa pola dari perdagangan internasional ditentukan oleh perbedaan dalam faktor pendukung. Model ini 
memperkirakan kalau negara-negara akan mengekspor barang yang membuat penggunaan intensif dari faktor pemenuh kebutuhan dan akan mengimpor barang yang akan menggunakan faktor lokal yang langka secara intensif. Masalah empiris dengan model H-o, dikenal sebagai Pradoks Leotief, yang dibuka dalam uji empiris oleh Wassily Leontief yang menemukan bahwa Amerika Serikat lebih cenderung untuk mengekspor barang buruh intensif dibanding memiliki kecukupan modal.

\section{Faktor spesifik}

Dalam model ini, mobilitas buruh antara industri satu dan yang lain sangatlah mungkin ketika modal tidak bergerak antar industri pada satu masa pendek. Faktor spesifik merujuk ke pemberian yaitu dalam faktor spesifik jangka pendek dari produksi, seperti modal fisik, tidak secara mudah dipindahkan antar industri. Teori mensugestikan jika ada peningkatan dalam harga sebuah barang, pemilik dari faktor produksi spesifik ke barang tersebut akan untuk pada term sebenarnya. Sebagai tambahan, pemilik dari faktor produksi spesifik berlawanan (seperti buruh dan modal) cenderung memiliki agenda bertolak belakang ketika melobi untuk pengednalian atas imigrasi buruh. Hubungan sebaliknya, kedua pemilik keuntungan bagi pemodal dan buruh dalam kenyataan membentuk sebuah peningkatan dalam pemenuhan modal. Model ini ideal untuk industri tertentu. Model ini cocok untuk memahami distribusi pendapatan tetapi tidak untuk menentukan pola pedagangan.

\section{METODE}

Data yang digunakan dalam penelitian ini adalah data sekunder runtun waktu selama periode Tahun 1993 sampai 2014, yang terdiri dari data pendapatan perkapita, nilai ekspor Indonesia ke Jepang dan investasi asing langsung. Data diperoleh dari Asian Development Bank dan Bank Indonesia.

Analisis data dilakukan secara deskriptif dan model regresi sederhana sebagai berikut:

Model pengaruh nilai ekspor ke jepang terhadap pendapatan perkapita Indonesia:

$$
\mathbf{Y p}=\boldsymbol{\beta} \mathbf{0}+\boldsymbol{\beta}_{1} \mathbf{X j}+\quad+\mathbf{e}
$$

Model pengaruh FDI terhadap pendapatan perkapita Indonesia:

$$
\mathrm{Yp}=\boldsymbol{\beta} \mathbf{0}+\beta_{1} \text { FDI }+\mathrm{e}
$$

\section{Dimana:}

Yp : Pendapatan perkapita

Xm : Nilai Ekspor ke Jepang

FDI : Investasi asing langsung

t : : Tahun 1993 sampai 2014

$\beta_{0} \quad$ : Konstanta

$\beta_{1} \quad: \quad$ Koefisien Regresi Variabel Independen

$\varepsilon \quad:$ Error term

\section{HASIL DAN PEMBAHASAN}

\section{Perkembangan PDB perkapita Indonesia}

Untuk mengetahui keadaan pendapatan perkapita Indonesia berdasarkan dari PDB Perkapita harga berlaku berserta perkembangannya dapat dilihat pada tabel berikut ini : 


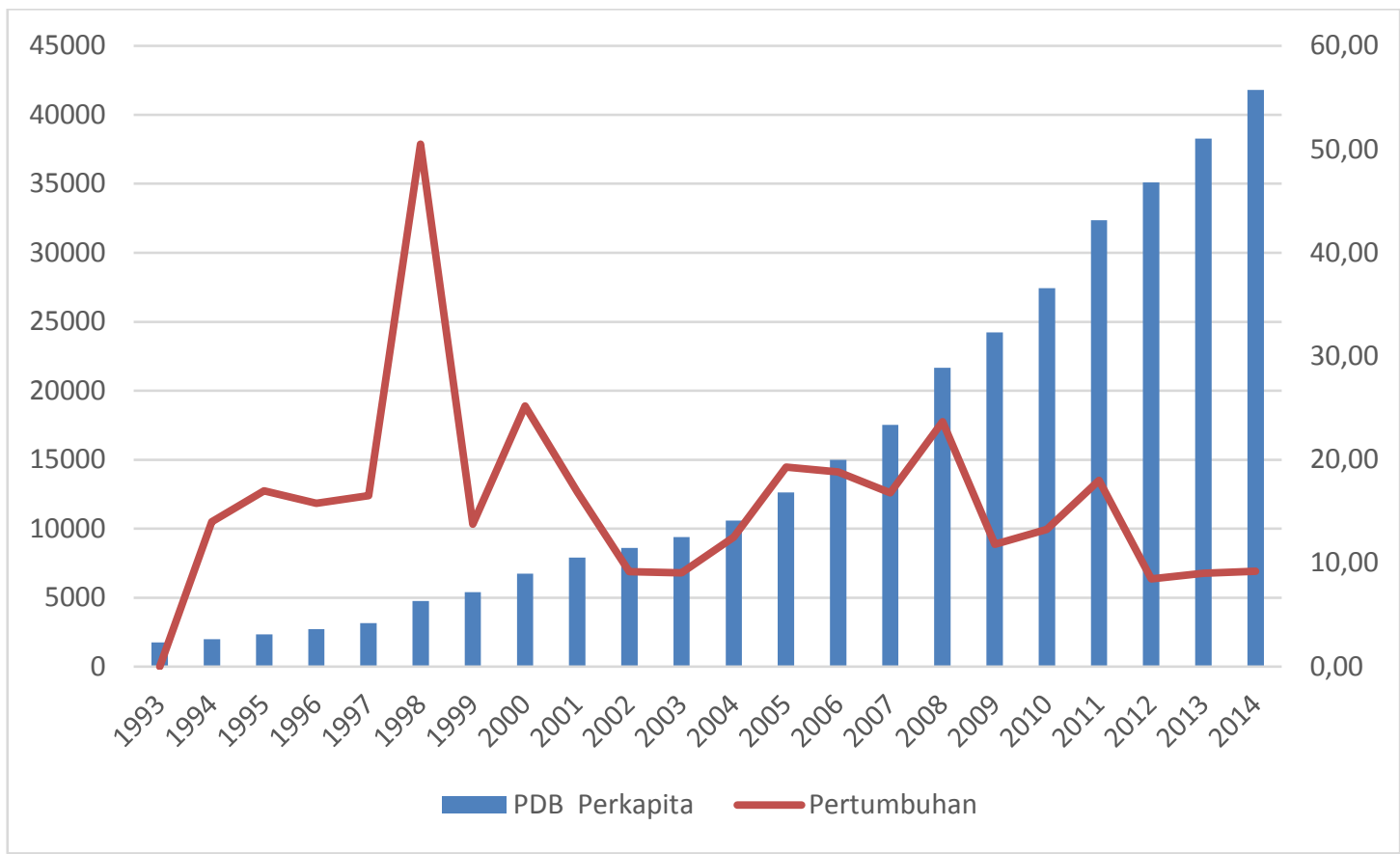

Gambar 1. Pendapatan perkapita Indonesia

Sumber : ADB (Asian Development Bank)

Berdasarkan gambar 1 terlihat bahwa PDB perkapita Indonesia selama periode penelitian mulai tahun 1993 sampai tahun 2014 mengalami fluktuasi atau naik turun dimana rata-rata nilainya adalah 15.058 dalam ribu rupiah pertahun dengan rata-rata pertumbuhan 16,61\% kemudian selama periode tersebut diperoleh hasil ternyata pertumbuhan tertinggi terjadi pada tahun 1998 yakni 50,50\% dan dengan pertrumbuhan terendah terjadi pada tahun 2012 yakni sebesar $8,46 \%$.

\section{Perkembangan FDI Indonesia}

Untuk mengetahui perkembangan FDI Indonesia selama periode tahun 1993 sampai 2014 dapat dilihat pada gambar 2. Berdasarkan Gambar 2 terlihat bahwa selama periode penelitian dari tahun 1993 sampai tahun 2014 nilai FDI Indonesia mengalami fluktuasi atau naik turun dengan nilai rata-rata 17.804,61 Juta US Dollar dan dengan rata-rata pertumbuhan $15,35 \%$, dari data diatas juga diperoleh hasil selama periode tersebut pertumbuhan FDI tertinggi terjadi pada tahun 1995 yakni 158,59\% dan pertumbuhan terendah terjadi pada tahun 1998 yakni $-59,91 \%$ hal ini kemungkinan pada tahun 1998 tersebut Indonesia mengalami krisis ekonomi dan krisis politik terjadinya peralihan kekuasaan dari presiden Suharto ke wakil presiden BJ.Habibi.

Krisis ekonomi pada tahun 1998 di ikuti dengan suasana politik dan keamanan yang cukup memanas sehingga menyebabkan variabel variabel ekonomi makro nilainya mengalami penurunan yang cukup tajam, salah satunya juga termasuk investasi dan FDI merupakan salah satu variabel investasi dengan keadaan politik dan keamanan serta ekonomi yang saat itu menurun menyebabkan banyaknya investor asing yang keluar dari Indonesia dan yang mau masuk pun membatalkan niatnya sehingga menyebabkan FDI Indonesia pertumbuhannya turun cukup tajam yakni sebesar $-59,91 \%$. 


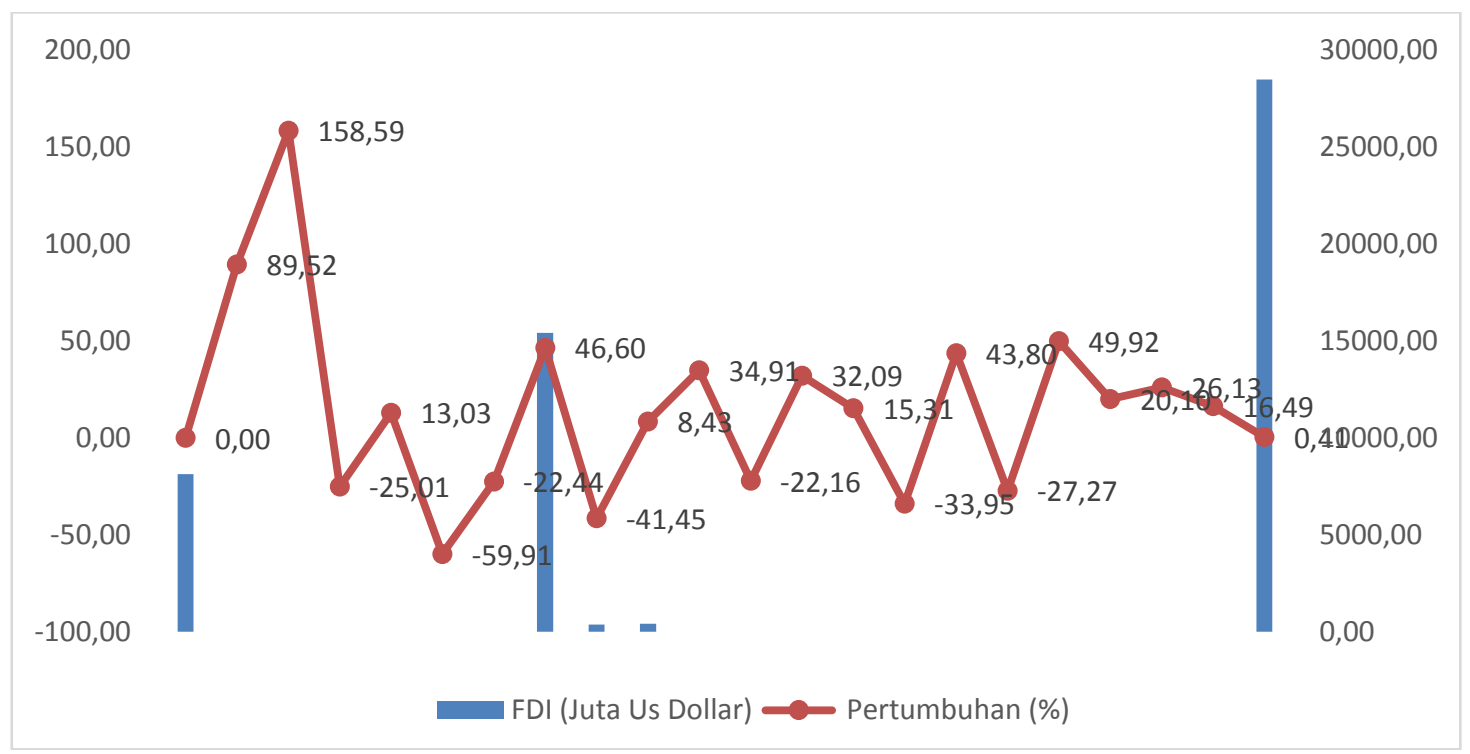

Gambar 2. Perkembangan FDI Indonesia

Sumber : Badan Pusat Statistik (BPS), (diolah)

\section{Perkembangan ekspor Indonesia ke Jepang}

Untuk mengetahui perkembangan nilai ekspor Indonesia ke jepang dapat dilihat pada gambar 3. Berdasarkan gambar 3 menunjukkan bahwa nilai ekspor Indonesia ke jepang selama periode tahun 1993 sampai tahun 2014 mengalami fluktuasi dengan ratarata nilainya adalah $18.087,5$ Juta US dollar dengan rata-rata nilai pertumbuhannya sebesar 5,32\% , dari data diatas juga terlihat bahwa selama periode tersebut rata-rata pertumbuhan tertinggi terjadi pada tahun 2010 yakni sebesar 38,79\% dan rata-rata pertumbuhan terendah sebesar $-26,98 \%$ yang terjadi pada tahun 1998 , sama halnya dengan FDI penyebab penurunan terendah ini karena pada tahun 1998 indonesia mengalami krisis ekonomi yang cukup parah sehingga ekspor ke jepang pun juga berdampak.

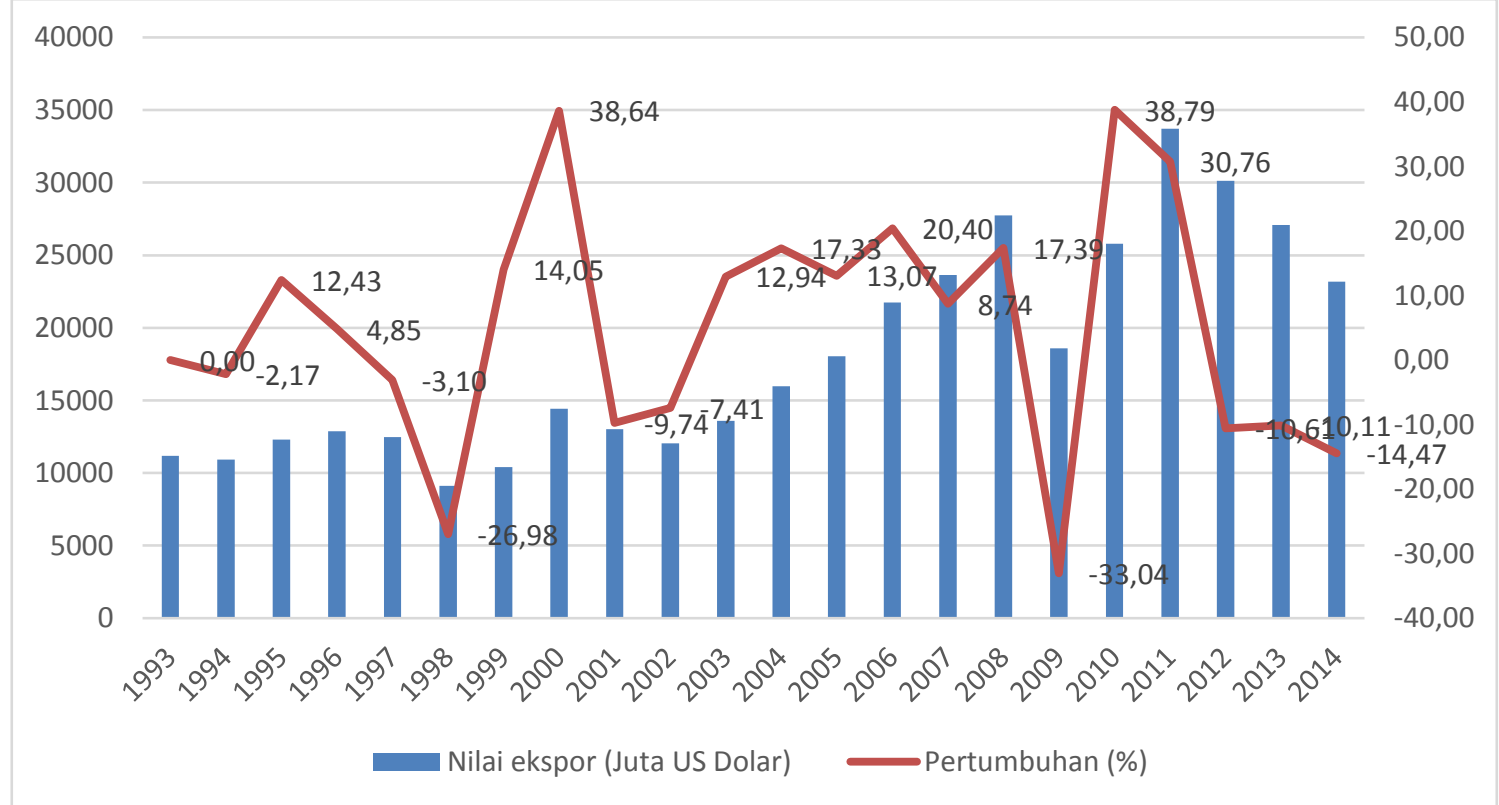

Gambar 3. Perkembangan nilai ekspor Indonesia ke Jepang Sumber : ADB (Asian Development Bank) 
Pengaruh nilai ekspor ke Jepang terhadap PDB Perkapita Indonesia

Untuk mengetahui pengaruh nilai ekspor ke jepang terhadap PDB perkapita dapat dilihat pada tabel berikut ini :

Tabel 1. Hasil regresi PDB perkapita dan nilai ekspor ke Jepang

\begin{tabular}{lclcr}
\hline \multicolumn{1}{c}{ Variable } & Coefficient & Std. Error & t-Statistic & Prob. \\
\hline C & -12804.53 & 3667.306 & -3.491536 & 0.0023 \\
XJPN & 1.540433 & 0.188563 & 8.169308 & 0.0000 \\
\hline R-squared & 0.769419 & Mean dependent var & 15058.05 \\
Adjusted R-squared & 0.757890 & S.D. dependent var & 12848.21 \\
S.E. of regression & 6321.912 & Akaike info criterion & 20.42794 \\
Sum squared resid & $7.99 \mathrm{E}+08$ & Schwarz criterion & 20.52712 \\
Log likelihood & -222.7073 & F-statistic & 66.73759 \\
Durbin-Watson stat & 0.917244 & Prob(F-statistic) & 0.000000 \\
\hline
\end{tabular}

Sumber : Data diolah, 2018

Dari hasil regresi tersebut diperoleh hasil nilai t hitung sebesar 8,169 dengan signifikansi mendekati alpha $1 \%$ sehingga dapat disimpulkan bahwa nilai ekspor ke jepang berpengaruh positif dan signifikan terhadap PDB perkapita.

Berdasarkan koefisien regresi dapat di interpretasikan bahwa pada saat nilai ekspor ke jepang berada pada posisi nol maka nilai PDB perkapita adalah sebesar 12804,53 dalam ribu rupiah sedangkan jika terjadi kenaikan ekspor ke jepang sebesar 1 Juta US dollar akan menyebabkan pendapatan perkapitan naik sebesar 1,54 dalam ribu rupiah.

\section{Pengaruh FDI Terhadap pendapatan perkapita}

Untuk mengetahui pengaruh FDI terhadap pendapatan perkapita dapat dilihat pada tabel berikut ini :

Tabel 2. Hasil regresi PDB perkapita dan FDI

\begin{tabular}{lrlcr}
\hline \multicolumn{1}{c}{ Variable } & Coefficient & Std. Error & t-Statistic & Prob. \\
\hline \multicolumn{1}{c}{ C } & 10501.12 & 6229.271 & 1.685771 & 0.1074 \\
\multicolumn{1}{c}{ FDI } & 0.255941 & 0.313617 & 0.816094 & 0.4241 \\
\hline R-squared & 0.032227 & Mean dependent var & 15058.05 \\
Adjusted R-squared & -0.016161 & S.D. dependent var & 12848.21 \\
S.E. of regression & 12951.61 & Akaike info criterion & 21.86234 \\
Sum squared resid & $3.35 \mathrm{E}+09$ & Schwarz criterion & 21.96152 \\
Log likelihood & -238.4857 & F-statistic & 0.666009 \\
Durbin-Watson stat & 0.055906 & Prob(F-statistic) & 0.424060 \\
\hline
\end{tabular}

Sumber : Data diolah, 2018

Dari hasil regresi diatas terlihat bahwa nilai $\mathrm{t}$ hitung adalah 0,816 dengan signifikansi melebihi batas toleransi alpha 10\% sehingga dengan demikian dapat disimpulkan bahwa FDI tidak berpengaruh signifikan terhadap PDB perkapita.

\section{KESIMPULAN DAN SARAN}

\section{Kesimpulan}

Selama periode penelitian mulai tahun 1993 sampai tahun 2014 PDB perkapita mengalami fluktuasi atau naik turun dimana rata-rata nilainya adalah 15.058 dalam ribu 
rupiah pertahun dengan rata-rata pertumbuhan $16,61 \%$ kemudian selama periode tersebut diperoleh hasil ternyata pertumbuhan tertinggi terjadi pada tahun 1998 yakni $50,50 \%$ dan dengan pertrumbuhan terendah terjadi pada tahun 2012 yakni sebesar $8,46 \%$. FDI Indonesia mengalami fluktuasi atau naik turun dengan nilai rata-rata 17.804,61 Juta US Dollar dan dengan rata-rata pertumbuhan 15,35\%, dari data diatas juga diperoleh hasil selama periode tersebut pertumbuhan FDI tertinggi terjadi pada tahun 1995 yakni 158,59\% dan pertumbuhan terendah terjadi pada tahun 1998 yakni 59,91\%, nilai ekspor Indonesia ke jepang selama periode tahun 1993 sampai tahun 2014 mengalami fluktuasi dengan rata-rata nilainya adalah 18.087,5 Juta US dollar dengan rata-rata nilai pertumbuhannya sebesar $5,32 \%$, dari data diatas juga terlihat bahwa selama periode tersebut rata-rata pertumbuhan tertinggi terjadi pada tahun 2010 yakni sebesar $38,79 \%$ dan rata-rata pertumbuhan terendah sebesar $-26,98 \%$ yang terjadi pada tahun 1998.

Dari hasil regresi pada kedua model diperoleh hasil bahwa pada model pertama nilai ekspor ke jepang berpengaruh positif dan signifikan terhadap PDB perkapita sementara variabel FDI tidak berpengaruh positif dan signifikan terhadap PDB perkapita.

\section{Saran}

Pemerintah harus terus memberikan upaya dan dukungan dalam meningkatkan ekspor ke jepang dan berupaya meningkatkan masuknya FDI ke dalam negeri yang langsung berhubungan dengan sektor yang dapat menggerakkan ekonomi rakyat sehingga dapat meningkatkan kontribusi terhadap PDB sehingga pendapatan perkapita pun akan meningkat. Bagi peneliti yang tertarik dengan variabel penelitian dalam penelitian ini di rekomendasikan untuk membuat model dengan memasukkan variabel waktu atau lag pada model kedua untuyk FDI atau dengan penelitian dengan jangkwa waktu yang lebih panjang.

\section{DAFTAR PUSTAKA}

Alkatiri, L. (2006).Analisa Pengaruh Foreign Direct Investment (FDI) dan Ekspor Terhadap Pertumbuhan Ekonomi. Centre Information Development Studies (CIDES): Jakarta

Asian Development Bank.(2005). Key Indicators For Asia and Pasific 2014. Asian Development Bank Statistics.

Balasubramanyam, V.N, M. Salisu., David S. (1996).Foreign Direct Investment and Growth in EP dan IS Countries. The Economics Journal.106(434),92-105.

Bank Indonesia. (2008). Laporan Perekonomian Indonesia Tahun 2008: Jakarta.

Bank Indonesia. (2013). Laporan Perekonomian Indonesia Tahun 2013: Jakarta

Blanchard, O. (2003).Macroeconomics.3rd Edition. Prentice-Hall.

Emilia, Rahma, N., Aminah, S. (2015).Analisis Pengaruh Ekspor ke China Terhadap Pendapatan Perkapita dan Penyerapan Tenaga Kerja di Indonesia. Jurnal Paradigma Ekonomika.10(2),326-337

Herlin,F., M,Rachmad,R., Safri, M. (2014).Produk Agroindustri Olahan yang Berdaya Saing Ekspor dan Dampaknya terhadap PDRB Provinsi Jambi. Jurnal Perspektif Pembiayaan dan Pembangunan Daerah.1(3), 143-148

Josef, K. (2007). Kajian Hubungan Antara Pertumbuhan Ekonomi, Perdagangan Internasional dan Foreign Direct Investment. Tesis, Fakultas Ekonomi Universitas Indonesia 
Mustika,C., Amril, Emilia. (2015). Analisis Pengaruh Ekspor ke Jepang Terhadap Pertumbuhan Ekonomi dan Jumlah Pengangguran di Indonesia Periode 1993 sampai 2013. Jurnal Paradigma Ekonomika.10(1),246-260

Mustika,C., Umiyati, E., Achmad, E. (2015). Analisis Pengaruh Ekspor Neto Terhadap Nilai Tukar Rupiah Terhadap Dolar Amerika Serikat dan Pertumbuhan Ekonomi di Indonesia. Jurnal Paradigma Ekonomika .10(2), 292-302

Tony, P.A. (2009).Analisis Hubungan Perdagangan Internasional dan FDI Terhadap Perekonomian Indonesia. Skripsi, Fakultas Ekonomi Universitas Indonesia 